\title{
Preparação e determinação de propriedades termomecânicas de TiO2 para aplicações em células solares
}

\author{
Júlia C. dos S. Carvalho*, Rafael B. Merlo, Francisco C. Marques.
}

\section{Resumo}

Para investigar as propriedades termomecânicas e ópticas de filmes de TiO2 compacto para aplicação como blocking layer e camada antirrefletora em células solars foram feitas deposições de filmes de $\mathrm{TiO}^{2}$ a $100^{\circ} \mathrm{C}$ através de deposições por camadas atômicas (Atomic Layer Deposition) em silício $<111>$ e germânio $<111>$, seguido por um recozimento a $500^{\circ} \mathrm{C}$ por 30 minutos. Após a compactação, as propriedades ópticas dos filmes, como índice de refração, transmitância e band gap foram otimizados e a tensão residual para o filme depositado em silício se tornou mais trativa, enquanto para o filme depositado em germânio observou-se maior compressividade.

\section{Palavras-chave:}

Atomic Layer Deposition, propriedades termomecânicas, stress.

\section{Introdução}

Blocking layers são um dos constituintes de células solares de perovskita e sensibilizadas por corantes, introduzidas para separar cargas fotogeradas e prevenir a recombinação de cargas [1]. Comparado ao óxido de zinco, dióxido de titânio (TiO2) é o material mais utilizado na fabricação de blocking layers, sendo também muito empregado em camadas antirrefletoras, cujo papel é minimizar a luz refletida na superfície do dispositivo. A introdução da camada antirrefletora é altamente significante no rendimento da célula solar visto que, para células de silício, a taxa de reflexão no infravermelho é de $30 \%$ e passa de $60 \%$ no ultravioleta [2].

Filmes de $\mathrm{TiO}_{2}$ podem ser facilmente depositados por ALD (Atomic Layer Deposition), um método de crescimento de filmes finos auto-limitante. A compactação dos filmes de $\mathrm{TiO}_{2}$ deve reduzir os defeitos estruturais e aumentar a mobilidade de portadores, otimizando sua atuação em aplicações fotovoltaicas e alterando as propriedades termomecânicas, como a tensão residual.

As propriedades termomecânicas são parâmetros importantes para se determinar a estabilidade dos dispositivos fabricados. Isto decorre do fato de que ocorrem deformações por conta da tensão, ou seja, deformações decorrentes das diferenças entre os coeficientes de dilatação térmica dos materiais em contato.

\section{Resultados e Discussão}

Foram depositados filmes de $\mathrm{TiO}_{2}$ a $100^{\circ} \mathrm{C}$ por deposição por camadas atômicas (ALD) utilizando como substratos silício <111>, germânio <111>. Posteriormente as amostras foram recozidas a $500^{\circ} \mathrm{C}$ por 30 minutos. Foram analisadas as fases dos filmes, as propriedades ópticas através do software PUMA e os raios de curvatura do substrato e dos filmes.

Foi observado que a compactação dos filmes gera um aumento na sua transmitância e no índice de refração na região visível do espectro e que o valor do gap passou de $3,1 \mathrm{eV}$ para $3,4 \mathrm{eV}$ após a compactação. A partir de medidas de stress em função da temperatura obtém-se o coeficiente de dilatação térmica e o módulo biaxial. 0 módulo de Young e a razão de Poisson são determinados a partir de medidas de nanoindentação, que caracteriza a dureza e o módulo elástico reduzido dos filmes.
A partir das medidas dos raios de curvatura (Tabela 1) é possível determinar o stress dos filmes (Tabela 2) pela fórmula de Stoney.

Tabela 1. Raios de curvatura do silício e germânio depositados a $100^{\circ} \mathrm{C}$ antes e após o recozimento.

\begin{tabular}{|c|c|c|}
\hline & Silício & Germânio \\
\hline Substrato & $119,4 \mathrm{~m}$ & $11,8 \mathrm{~m}$ \\
\hline $\mathbf{1 0 0}^{\circ} \mathbf{C}$ & $147,9 \mathrm{~m}$ & $13,5 \mathrm{~m}$ \\
\hline $\mathbf{1 0 0}^{\circ} \mathbf{C}+$ annealing & 110,9 & 57,1 \\
\hline
\end{tabular}

Tabela 2. Valores de stress do silício e germânio depositados a $100^{\circ} \mathrm{C}$ antes e após o recozimento.

\begin{tabular}{|c|c|c|}
\hline & Silício & Germânio \\
\hline $\mathbf{1 0 0 ^ { \circ } \mathbf { C }}$ & $-47 \mathrm{MPa}$ & $-0,14 \mathrm{GPa}$ \\
\hline $\mathbf{1 0 0 ^ { \circ } \mathbf { C }}+$ annealing & $22 \mathrm{MPa}$ & $-1,04 \mathrm{GPa}$ \\
\hline
\end{tabular}

A partir da Tabela 2, observa-se que a compactação tornou o filme depositado em silício mais trativo, enquanto o filme depositado em germânio se torna mais compressivo.

Foi observado que a espessura dos filmes, de $330 \mathrm{~nm}$, é insuficiente para realizar medidas de propriedades termomecânicas. Por conta disso, estão sendo preparados filmes com espessuras de $1 \mu \mathrm{m}$ utilizando como substratos silício <111>, germânio <111>, quartzo z-cut, sílica e vidros 7059 e 211.

\section{Conclusões}

A partir das medidas realizadas, é possível inferir que a compactação dos filmes de $\mathrm{TiO}_{2}$ depositadas por ALD otimiza suas propriedades ópticas para aplicação como blocking layer para células solares; as variações nas propriedades termomecânicas estão sendo estudadas. Não foi possível realizar medidas de stress em função da temperatura e nanoindentação por conta da espessura dos filmes preparados.

\section{Agradecimentos}

Ao CNPQ e à FAPESP, pelo financiamento desta pesquisa.

\footnotetext{
${ }_{1}^{1}$ LIU, Huijing et al. Thickness-dependent photovoltaic performance of $\mathrm{TiO} 2$ blocking layer for perovskite solar cells. Journal Of Alloys And Compounds, v. 736, p.87-92, mar. 2017. Elsevier BV. http://dx.doi.org/10.1016/j.jallcom.2017.11.081.

2 RODRÍGUEZ, Daniel Fabián; PERILlO, Patricia María; BARRERA, Marcela Patricia. High performance TiO2 nanotubes antireflection coating. Materials Science In Semiconductor Processing, v. 71, p.427-432, nov. 2017. Elsevier BV. http://dx.doi.org/10.1016/j.mssp.2017.08.037.
} 